\title{
David Martin: My Teacher, or, A Way of Seeing
}

\author{
Athena S. Leoussi ${ }^{1}$ \\ Published online: 13 March 2020 \\ (C) The Author(s) 2020
}

\begin{abstract}
David Martin's sociology of religion embodied an expansive vision of religion, one that encompassed the entirety of human and social experience: its political, national, economic, aesthetic, poetical and spiritual-religious orientations, and the complexities of their institutional arrangements, entanglements and compromises with one another. David's sociology was not formulaic; it was a constant struggle - a struggle for understanding the motives, forms and patterns of human behaviour as these changed and shifted under changing circumstances. David was extraordinarily sensitive to the importance of the historical context, and especially the effects of modernity, in all its different guises, on the great cultural traditions of Western civilisation: Christianity and Western 'high culture' - the 'Western canon' of European art, music, literature and poetry. For David, the former presented the best account of human life; the latter, the pinnacles of human creative and imaginative achievement. As my doctoral supervisor, he also helped me to see and understand the persistence, revival and evolution of that other great European cultural tradition, the Classical tradition, the civilisation of the ancient Greek and Roman worlds, in the modern world. Like its Biblical, Judaeo-Christian, counterpart, the Classical tradition has offered, well into the twentieth century, a powerful repertoire of cultural themes, images and symbols of human existence. This repertoire was often seen to parallel and complement the Biblical repertoire, while in its artistic, musical, and literary manifestations, would form the basis of the 'Western canon'. Modern cultural movements, and especially the expressive and utilitarian revolutions of the 1960s, would set out to break these great images of the axial age. David's mission would be to restore them.
\end{abstract}

Keywords Classicism · Hebraism · Nationalism · Art · The 'Western canon' · Cultural repertoire

I am immensely proud and deeply grateful to be able to say that David Martin was my teacher. He was my teacher in the fullest, or rather Greek sense of the word. He taught me both how to live and how to think. He communicated to me, and almost without words, in his distinctively and brilliantly subtle manner, and in a way similar to the way burning incense communicates the sense of the divine, the spiritual dimension of human life - the spirituality of Christianity and of Judaism, with which Protestantism tends to fuse. And he taught me how to think; not in the sense of indoctrination, but that of intellectual and spiritual emancipation and aspiration, both to know and to understand, in Max Weber's sense of Verstehen (being himself a Weberian); but also in Johann Gottfried von Herder's sense of Einfühlung, "feeling one's way into" the thought inside the texts, the words, the things, the acts.

Athena S. Leoussi

aleoussi@aol.com

1 Department of Languages and Cultures, University of Reading, Whiteknights PO Box 217, Reading, Berkshire RG6 6AH, UK
David's guidance was of pivotal significance to me during my years as a young PhD student in the Sociology Department at the London School of Economics. It was in the late 1980s that he kindly and trustingly agreed to be my supervisor, and recommended Anthony D. Smith, a leading scholar of nationalism, as co-supervisor. David shared many things with Anthony. Most importantly, they shared the conviction of the Biblical roots of nationalism, and a passionate love of art and music as life-enhancing and lifetranscending. I was innocent and very ignorant, at that time. Soon, however, I realised that I was truly standing 'on the shoulders of giants'.

David understood the role and value of education in shaping lives. He often spoke of 'formation', placing the accent on the last syllable, to refer to its meaning in French, that described education, or at least a good education, more accurately, as a deeply transformative process. He gave to the autobiographical book that he published in 2013, the title, The Education of David Martin, thereby emphasising the role of his parents and of his schooling in shaping his adult life as not only a sociologist, but a sociologist of religion, and, coming round full-circle, in later life, 
as a priest. ${ }^{1}$ My education by David was radically transformative. It was like a conversion and a re-birth.

The experience of being formed, and, indeed, transformed by David Martin was an extraordinary experience. My undergraduate studies in Sociology in France, at the University of Grenoble, had a sobering and cooling effect on me, with abstract social theory lectures on structures sociales, uninhabited by real men and women, and history lectures in which history began and ended with the French Revolution. It was only through the anthropology lectures that we could explore, albeit through the lens of Claude Lévi-Strauss, some of the flesh and blood realities of human life and its 'structural' and varying responses to its environments. However, between the anthropologists' societies and those born, supposedly fully formed, of the French Revolution, there was what Ernest Gellner liked to refer to, with approval, 'the Big Ditch'. ${ }^{2}$ With David Martin, I learnt that this was not so. I learnt about tradition, both religious and national, and its persistence over 'the Big Ditch'.

My doctoral dissertation was in the sociology of the Classical Greek revival in English and French art in the second half of the nineteenth century. It would be the leitmotiv of my research for most of my life as an academic. Under David's tutelage, I would gradually, gently and with enormous excitement, discover that this was a much more complex enquiry than I had originally imagined and was led to understand from reading books on nineteenth-century European art, during my MPhil at the Courtauld Institute of Art, of the University of London. ${ }^{3}$ These paintings and sculptures of ancient Greek gods and goddesses, heroes, heroines and athletes, these scores of Perseuses and Andromedas, Psyches, and Clities, Parises and Helens, Persephones and Demeters, Aphrodites and Apollos, Pantarceses and Discoboloi, delved in the very wellsprings of European culture, and involved multiple, shifting and intertwining influences, values, and modes of conduct. Victorian art had cultural meaning. It was not escapist, or purely aestheticist, as standard art histories had claimed - it was deeply rooted, and replete with existential, vital content; neither was it a passive agent of other forces, as some sociologists had claimed, but, rather, a force in itself and a factor in its own right in bringing about broad cultural change. The same applied to the art of the French Third Republic.

David gave me the fundamental intellectual tools to understand the profound and wider implications of this 'modern' Classical revival, or rather series of Classical revivals. Among

\footnotetext{
${ }^{1}$ David Martin The Education of David Martin: The Making of an Unlikely Sociologist. London: Society for Promoting Christian Knowledge, 2013.

${ }^{2}$ Ernest Gellner. Spectacles and Predicaments: Essays in Social Theory. Cambridge: Cambridge University Press, 1979.

${ }^{3}$ My doctoral dissertation was eventual published under the title, Nationalism and Classicism: The Classical Body as National Symbol in NineteenthCentury England and France. Houndmills, Basingstoke/New York: Macmillan Press/St. Martin's Press, 1998.
}

the many insights that David gave me, three were of crucial significance:

The first insight that David gave me into the material at hand, was, naturally, Sociological. He provided me with entry points into Sociology through his assignments in social theory, in preparation for my doctoral research. These assignments introduced me to what I recognised to be the best in Sociological thinking. He gave me two assignments: two essays to write - one on Émile Durkheim, and another on Max Weber. Durkheim was already familiar to me, from my studies in France. But it was only through my tutorial discussions with David that I came to understand Durkheim's significance and, above all, his concept of the conscience collective and the full, concrete meaning of social solidarity as the human relationship, as the give and the take between men and women, as the common endeavour and as the experience of being members, one of the other. These would be the concepts that would help me understand both human life and the phenomena of nation and nationalism, which the comparative perspective of England and France that I had adopted, implied. Attendance of the postgraduate seminars in the Sociology of Religion, which David chaired with Eileen Barker, also helped burn the mist of ghostly concepts. These seminars were beacons of genuine enquiry, conducted without fear of doctrinal non-conformity, either religious or political, but with anxious regard for factual accuracy, relevance and coherence. They were also training grounds for critical thinking and, to my surprise, had a scope that embraced the entire gamut of human experience. I did not attend religiously, especially as my research progressed, data collection was taking longer than I thought, and my three-year scholarship was drawing to an end; but it was for me an intellectual refuge and one in which I always felt welcome.

When Weber's turn came, David asked me to read The Protestant Ethic and The Spirit of Capitalism. I read every page of it - very-very-very slowly, over a period of several months, and so many deadline extensions. David would always wait patiently for me. To my delight, he was quite impressed with the essay - so impressed that he even thought that it might have been written by somebody else - which it was not. And this suspicion further enhanced my delight. With Weber, I learnt about Kulturgeschichte, the diversity of human motives, the multiple and symbolic meanings of human behaviour and the aim of sociology as a quest for Verstehen understanding of human behaviour.

With David, I understood the real vocation of Sociology and also the terrific demands of this vocation; above all, the demand to acknowledge the interconnectedness of all of the humanities and of them with all of the social sciences; and, thus, the necessity to know everything! He was an exemplar of this vision of Sociology as a calling for the polymath - not the reductionist.

The two essays on Durkheim and Weber would bring me closer to Sociology. They marked a new beginning in my intellectual upbringing, in David's charge. 
My next steps were taken in the direction of the actual substance, the primary data of my doctoral research: the works of art on Classical themes. In order to enable me to take these steps, David suggested that I read two books: Kenneth Clark's The Nude ${ }^{4}$ and Lucien Goldmann's The Hidden God. ${ }^{5}$ These brilliant books on Western art and literature provided me with the second insight into the Classical revival: the cultural, historical and societal embeddedness of works of art and literature. They also provided me with the methods for reconstructing and recognising 'world visions', a concept that was Goldmann's idée maittresse in The Hidden God, in particular features of works of art. These 'world visions' would constitute the meaning of works of art. From reading these books I understood that my quest was a quest for meaning an inquiry into the cultural significance of art. It was an application of the Weberian quest for Verstehen. Kenneth Clark's The Nude further led me to the realisation of the humanism of Western culture, a humanism that originated in classical antiquity, and was expressed in the centrality of the image of the nude, the uncovered human body, in Western art. This centrality was evident in the survival and migration of the nude over the centuries, even during the Middle Ages (e.g., in the naked image of Jesus on the Cross), and into the twentieth century. Clark's The Nude had an additional value: it provided a system of classification, a list of types or recurring forms through which the human body had signified different emotional and cultural orientations.

It was not so much the insights into my research material that this second set of David's reading suggestions gave me that were striking, however crucial they were. What was really striking was, first, his very knowledge of these books, and second, his knowledge of both the art and the literature that these books analysed. He saw immediately that Classicism in European art was about the nude - the human body, and through it, human values and visions. David seemed to have seen the whole of Western art and to have read the whole of Western literature in both prose and poetry - and to be remembering it all. Moreover, he showed an impressive openness of mind. For I was somewhat surprised when, reading around Lucien Goldmann, I realised that he was a Marxist thinker - an enthusiast of dialectical materialism. ${ }^{6}$ This, however, had not deterred David from reading and appreciating The Hidden God. He recognised the importance of Goldmann's book, the wider scope of his argument, and his detailed literary and cultural analysis of the actual works of philosophy and literature. Indeed, David suggested that The Hidden God might well

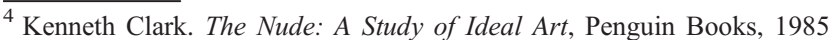
[1956].

5 Lucien Goldmann. The Hidden God: A Study of Tragic Vision in the Pensées of Pascal and the Tragedies of Racine. London: Routledge \& Kegan Paul, 1964.

${ }^{6}$ Grimsley, R. (1965), 'The Hidden God' review. Philosophical Books, 6: 1012
}

offer itself as a model or pattern to follow in the analysis of my visual material. It did. And I was able to trace and match visual image and 'world vision'.

The third and most original, incisive and important insight that David gave me, was his own understanding of nineteenth-century European Classicism. It was an insight that defined the very essence of artistic and societal orientation to Classical antiquity. David saw Classical civilisation as a 'repertoire' of cultural themes or motifs. Under different circumstances, Western societies have been attached to this or that theme from its rich repertoire, adopting and adapting it to these circumstances. This powerfully analytical perspective enabled me to look for and identify, during my doctoral research and afterwards, during my research as an academic, the distinctive motifs of nineteenth-century European Classicism: citizenship and the athletic body. Concern with political freedom, identity, and the physical dimension of human nature led Classically-educated European elites, who had faith in the authority of Classical civilisation, a civilisation believed to stand above time, to find there a path, a solution, to modern problems. The solutions were revivals and modern inflections, or adaptations, of the Classical cults of the citizen and of the athletic body. These revivals would transform European nations into nations of citizens and athletes. They would become core components of national identity across Europe and beyond.

I could thus see Classical revivalist movements as presenting parallels with Christian revivalist movements. The motif of war (violence) and peace, for example, which was at the heart of David's life-long intellectual quest, had found, in the Middle Ages, Christian expression and limitation in the notion of chivalry. ${ }^{7}$ In this way, Christianity, with its cult of love, far from causing war, would soften, temper and channel the outburst of brute violence.

As it happened, the nineteenth-century material showed me the intertwining of both Classical and Christian revivalist movements, in the attempt, not only in England, but also in France, to forge the synthesis of what Matthew Arnold (18221888) had described, in the famous fourth chapter of Culture and Anarchy (1867-68), and following that other great thinker of the mid-nineteenth century, the German Jewish Heinrich Heine (1797-1856), as "Hellenism and Hebraism" - a new Renaissance. $^{8}$ David's concept of cultural traditions as

\footnotetext{
${ }_{7}^{7}$ David Martin. Pacifism: A Historical and Sociological Study. London: Routledge and Kegan Paul, 1965; David Martin. Does Christianity Cause War? Clarendon Press, 1997.

${ }^{8}$ Arnold, Matthew Culture and Anarchy. An Essay in Political and Social Criticism. Edited with an introduction by John Dover Wilson, Cambridge: Cambridge University Press (first edition London 1869: Nelson \& Sons), 1990. On Heine's influence on Arnold, see, Arnold, Matthew Essays in Criticism, London: Macmillan \& Co. Ltd., 1902 (first published 1865).
} 
'repertoires' of themes gave me the key to understanding not only the nineteenth-century Classical revival, but the entire Classical tradition that has been embedded in Western societies, and provided key elements of the Western canon. Like its Christian counterpart, the Classical tradition has been not merely an undercurrent in Western culture; it has also manifested itself in great tidal waves of social and cultural renewal through revival of various themes. This was so until the First World War. The twentieth century, through its series of cultural revolutions that culminated in the student and youth movements of the 1960s, would challenge the cultural centrality of both Christianity and of the 'Western canon' - the 'high culture' of Europe, its art, music, literature and poetry, as offering pinnacles of human creative and imaginative achievement. And David would fight for both. This he did through his writings and in practice - the practice of the rites of the Christian Sacraments as an Anglican priest, and, as a talented pianist and singer, that of the Western musical canon. Of course, the priesthood, the piano and the song were intimately connected, not least, by the fact that much of the Western musical canon has been sacred - it has been Christian music; music as 'the handmaiden of religion'. Religious has been much of the music of G. F. Handel, but also of J. S. Bach, and of Ludwig van Beethoven and of many others.

As art, religion and national identity were closely intertwined, the one being a part of the other, and the one mutating into the other, David was close to Anthony D. Smith and I benefited immensely from their exchanges, and of their knowledge and appreciation of each other's work. They both saw how nation and religion offered men and women entry points to the sense of place, time, meaning and belonging. Furthermore, national identity would overlap with religion, transforming it into 'our' religion, and, in return, religion (and especially Biblical religion) would sacralise nationality, making the group the bearer of holiness and its preservation a sacred mission. ${ }^{9}$ Both religion and nationality would find expression and sustenance in the symbols and images of art.

When a number of doctoral students, me included, founded, with Anthony D. Smith, the Association for the Study of Ethnicity and Nationalism (ASEN) at LSE, in the 1990s, David would fully support it, participate in its series of public lectures, and constantly act as reviewer of article submissions to ASEN's journal, Nations and Nationalism. Invited to give one of the annual Ernest Gellner Nationalism Lectures of Nations and Nationalism, on 8 April 2013, he delivered a tour de force of incisive observations and hypotheses on the relationship between religion and nationalism. He unleashed what he called his 'intellectual troops' in three different directions: 'the ethno-

\footnotetext{
${ }^{9}$ Smith, Anthony D. Chosen Peoples: Sacred Sources of National Identity, Oxford: OUP, 2003; Martin, David 'Nationalism and religion'. Nations and Nationalism, 20: 1-17, 2014.
}

religious revolutions of 1989 , the global upsurge of Evangelicalism and Pentecostalism and the Islamist revival as presented in the so-called Arab Spring', in an exploration of the place of nationalism in a world of transnational religious movements, transnational Evangelicalism and Islamism, and of the internet that globalises the imagination of young people with access to it. One of the many conclusions that he drew from this global exploration of 'the powerful bastions of collective identity', the religious and the national communities, was their erosion by 'incursions of personal choice', by secularising individualisation. ${ }^{10}$

It is impossible to give a full list of David's intellectual and spiritual gifts to me, or to describe the many and mostly implicitly and subtly insinuated to me, ways in which, through him, I was able to see the world and communicate this vision to others, through my own writings. Nevertheless, one way of seeing and understanding the world was made absolutely clear to me, from talking to and reading David' writings: the way of the metaphor. David showed to me, over and over again, how much more powerful a metaphor could be as compared to sterile and blind jargon. And he was the master of metaphor, as in a description of Talcott Parsons as 'physically and psychologically deaf'! He recognised the clarity and potency with which metaphorical images, parables, parallelisms and poetry could convey meaning. It was for this reason that he deeply regretted the 'breaking of the image', the prosaic reforms of both the Christian Liturgy and of the Book of Common Prayer and the King James Bible. ${ }^{11}$

I should like to end this tribute to David Martin with the words of Kenneth Minogue in his obituary of Elie Kedourie, which apply equally to him: 'The loss of a friend and colleague is always sad; but the loss of a scholar has a further dimension: scholars take years to accumulate a density of detailed understanding which is irreplaceable. ${ }^{12}$

David enabled me to see the world in entirely new ways. And he held my hand, guiding me and supporting me through both my personal and professional life, and 'unto this last'. My relationship with him and my memories of him are among my most precious possessions. He continues to live and shine in my mind, through his teachings and his writings.

Open Access This article is licensed under a Creative Commons Attribution 4.0 International License, which permits use, sharing, adaptation, distribution and reproduction in any medium or format, as long as you give appropriate credit to the original author(s) and the source, provide a link to the Creative Commons licence, and indicate if changes were made. The images or other third party material in this article are included in the article's Creative Commons licence, unless indicated otherwise in a credit line to the material. If material is not included in the article's

\footnotetext{
${ }^{10}$ David Martin. 'Nationalism and religion'. Nations and Nationalism, 20: 14, 2014.

${ }^{11}$ David Martin: The Breaking of the Image: A Sociology of Christian Theory and Practice, Basil Blackwell, Oxford 1980.

${ }^{12}$ Kenneth Minogue. Obituary: 'Professor Elie Kedourie', Independent, 3 July 1992.
} 
Creative Commons licence and your intended use is not permitted by statutory regulation or exceeds the permitted use, you will need to obtain permission directly from the copyright holder. To view a copy of this licence, visit http://creativecommons.org/licenses/by/4.0/.

Publisher's Note Springer Nature remains neutral with regard to jurisdictional claims in published maps and institutional affiliations.
Athena S. Leoussi is Associate Professor in European History in the Department of Languages and Cultures of the University of Reading, UK. She is a Founder of the Association for the Study of Ethnicity and Nationalism and a Founding and continuing Editor of the journal, Nations and Nationalism. 